\title{
Memperkokoh Hubungan Indonesia-Australia
}

\author{
Vinsensio M. A. Dugis \\ Departemen Hubungan Internasional FISIP Universitas Airlangga
}

\begin{abstract}
ABSTRAK
Upaya-upaya apa yang dapat dilakukan pemerintah Indonesia dan Australia untuk memperkuat kembali hubungan bilateral Indonesia Australia? Pertanyaan ini tepat untuk diangkat, mengingat Presiden Joko Widodo (Jokowi) resmi dilantik ketika hubungan Indonesia-Australia sekali lagi berada pada titik rendah menyusul terkuaknya upaya skandal penyadapan yang dilakukan para agen intelijen Australia terhadap sejumlah petinggi Indonesia. Situasi kemudian semakin memburuk menyusul penolakan Presiden Jokowi atas permohonan grasi dua terpidana mati warga Australia yang dinyatakan bersalah tahun 2006 sebagai otak perencanaan penyelundupan heroin dari Bali. Tulisan ini berpendapat bahwa kedua pemerintahan dapat belajar pada praktek yang pernah dilakukan semenjak pertengahan tahun 1980an, yaitu membangun kembali hubungan bilateral yang diawali dengan diplomasi pertemanan. Komunikasi hotline langsung antar pemerintah kedua belah pihak diperluas sementara hubungan antarorang tidak saja diperluas tetapi juga diperdalam. Cara ini membuka banyak kesempatan bagi kedua pihak dapat menemukan kepentingan-kepentingan serupa, yang selanjutnya tentu saja menjadi benih-benih unggul demi membangun kerjasama yang semakin lebih berarti ke depan.
\end{abstract}

Kata Kunci: hubungan bilateral, diplomasi, diplomasi pertemanan

What the current governments of Indonesia and Australia can do to restrengthen its bilateral relationship? This question is timely to be raised up, as President Joko Widodo (Jokowi) assumed his presidency when IndonesiaAustralia relationship was once again at its low point following the revelations of Australia's spy agencies targeted Indonesia's high ranking officers. The relationship further deteriorated following the refusal of President Jokowi over the request clemency from death sentence of two Australians, found guilty in 2006 of being the ringleaders of a gang which plotted to smuggle heroin out the country from Bali. This paper is on the view that in order to revitalize the bilateral relationship of Indonesia and Australia, both governments can learn from what once utilized since the 1980s, that is building relations by a so-called setting up a mateship diplomacy. Direct hotline communications between officers needs to be broadening while at the same time people-to-people contact at large needs to be deepened. This way would give both side ample vanues where both governments could see more shared similiarties of interests, which eventually becoming fertile seeds for a further meaningful collaborations.

Keywords: bilateral relationship, diplomacy, mateship diplomacy, 
Sejarah hubungan bilateral Indonesia-Australia semenjak tahun 1945 senantiasa diwarnai grafik turun naik (Dugis 1997). Terdapat periode dimana hubungan kedua negara tetangga ini begitu hangat, dekat dan stabil, tetapi ada juga momen dimana hubungan tersebut dingin, menjauh dan penuh kegaduhan (Catley \& Dugis 1998). Siklusnya ibarat mengikuti putaran roda roller-coaster, situasi hubungan yang krisis umumnya disusul dengan berbagai upaya perbaikan yang dilakukan kedua pihak menuju titik kedekatan yang stabil.

Salah satu isu yang senanatiasa menjadi pertanyaan luas publik semenjak kampanye pemilihan presiden tahun 2014 ialah bagaimana Presiden Joko Widodo (Jokowi) mengelola hubungan luar negeri Indonesia. Satu dari banyak isu yang ketika itu sempat mencuri perhatian adalah menyangkut prospek hubungan Indonesia-Australia. Perhatian muncul menyusul terkuaknya skandal penyadapan komunikasi yang dilakukan agen mata-mata Australia terhadap sejumlah pejabat tinggi di Indonesia, termasuk Presiden Susilo Bambang Yudoyono (SBY). Terkuaknya skandal penyadapan ini, membuat geram pemerintah Indonesia. Desakan permintaan maaf tidak digubris pihak Australia, dan hal ini mengakibatkan Jakarta memanggil pulang untuk sementara waktu Duta Besar Indonesia untuk Australia pada tanggal 19 November 2013, sebagai bentuk protes keras terhadap sikap Australia. Tidak berhenti disitu, sehari setelah pemanggilan pulang Duta Besar itu, Indonesia secara resmi menangguhkan pelaksanaan kerjasama di bidang hukum dan militer (military and law enforcement cooperation) (Roberts \& Habir 2014, 90). Hubungan persahabatan Jakarta-Australia yang selama dua periode kepemimpinan Presiden SBY diwarnai kestabilan, kali ini kembali mengalami gangguan, ditandai dengan ketegangan diplomatik yang berlangsung (Prabaningtyas 2013).

Walau demikian, upaya perbaikan nampaknya dilakukan kedua belah pihak. Meskipun untuk sementara waktu Indonesia tanpa Duta Besar di Canberra, komunikasi di tingkat elit tetap berjalan. Hasilnya terlihat ketika Indonesia pada akhir bulan Mei 2014 memutuskan untuk kembali mengirim Duta Besar ke pos di Canberra yang sempat kosong semenjak November 2013. Tidak lama setelah ini, tanggal 4 Juni 2014 Perdana Menteri Australia, Tony Abbott, menemui Presiden SBY di Batam. Abbott menyambangi Batam karena menyesuaikan dengan jadwal Presiden SBY yang ketika itu akan membuka MTQ di Batam. Salah satu yang dianggap signifikan dari upaya normalisasi hubungan ini ialah kunjungan Wakil Presiden Budiono ke Australia pada bulan Agustus 2014. Walaupun demikian, proses normalisasi hubungan ini belumlah sepenuhnya pulih sebagaimana situasi sebelum terkuaknya skandal penyadapan. 
Di bawah warisan kondisi 'mendinginnya' hubungan bilateral inilah Presiden Jokowi naik menjadi orang nomor satu di Indonesia (Connelly 2014). Kehadiran Perdana Menteri Tony Abbott pada saat pelantikan Presiden Jokowi memberi signal jelas bahwa pihak Australia antusias memperbaiki hubungan bilateral dengan Indonesia. Tetapi, tanda-tanda membaiknya hubungan ini rupanya pupus menyusul keputusan eksekusi terhadap dua warga Negara Australia terpidana mati kasus penyelundupan narkoba, Andrew Chan dan Myuran Sukumuran. Protes keras pihak pemerintah dan publik Australia terhadap keputusan tersebut, serta berbagai upaya lain yang dilakukan pemerintah Australia, tidak menggoyahkan keputusan Indonesia. Puncaknya ketika Presiden Jokowi menolak permintaan grasi dari pihak Australia atas kedua terpidana mati tersebut (Roberts, 2015). Eksekusi tetap berjalan, dan sebagai bentuk protes pemerintah Australia, Duta Besar Australia di Jakarta ditarik kembali ke Canberra (Scott \& Chatterjee 2015). Hubungan kedua negara kembali jatuh ke titik yang semakin rendah.

Semenjak itu berbagai upaya normalisasi kembali dilakukan. Sebulan sejak ditarik, Duta Besar Australia untuk Jakarta kembali menempati posnya di Jakarta. Upaya memperkuat kembali hubungan kedua negara bersahabat ini tentu membutuhkan waktu. Dalam kaitannya dengan itu, sebagaimana diungkap di awal tulisan ini, Jakarta dan Canberra dapat mengambil pelajaran dari apa yang pernah dilakukan pemerintah kedua negara sejak pertengahan tahun 1980an, yaitu mengembangkan fondasi hubungan bilateral yang dibangun dengan asas pertemanan, baik pada level pemerintahan maupun pada level masyarakat (people-to-people relationship). Fondasi hubungan ini disebut Diplomasi Pertemanan (Mateship Diplomacy), sebuah bentuk diplomasi yang pernah dibangun dan dikembangkan pemerintah kedua negara menyusul memburuknya hubungan Australia-Indonesia akibat tulisan wartawan The Sydney Morning Herald, David Jenkins, dalam edisi 10 April 1986 harian tersebut. Tulisan ini menyingkap kembali (revisited) bagaimana bangunan hubungan tersebut dibentuk, dan pelajaran apa yang dapat dipetik untuk membangun hubungan Indonesia-Australia yang lebih bermakna ke depannya.

\section{Jenkins Affair \& Mateship Diplomacy}

Dalam edisi 10 April 1986, David Jenkins, wartawan The Sydney Morning Herald, menguraikan tentang bisnis keluarga Soeharto dan kroni-kroninya. Ia menganalogikan keberuntungan keluarga Soeharto dengan keluarga Marcos di Philipina yang mengantarkan ke kejatuhannya akibat people's power revolution (Jenkins 1986a, 1; 1986b, 7). Peristiwa ini menyebabkan Pemerintah Indonesia bereaksi keras, menganggap artikel itu bohong dan menghina (Walters 1986a, 1). 
Di Jakarta, Menlu Indonesia memanggil Dubes Australia dan di Canberra, Dubes Indonesia mengajukan surat protes kepada Menlu Ausralia berkaitan dengan artikel Jenkins. Tanggal 12 April 1986, Menristek Habibie membatalkan secara sepihak rencana kunjungannya ke Australia (Byrnes 1986a, 1-4). Tidak lama kemudian, Indonesia menolak perpanjangan visa masuk jurnalis Australia dan melarang masuk sembilan orang jurnalis yang ingin meliput kunjungan Presiden AS, Ronald Reagan, ke Bali (Walters 1986b, 1). Hubungan semakin memburuk ketika Indonesia secara sepihak menunda perundingan mengenai batas landas kontinen di Celah Timor (Byrnes 1986b, 1-4).

Menghadapi sikap Indonesia, Australia tidak tinggal diam. Tanggal 21 April 1986, secara sepihak Australia mencabut hak berlabuh nelayan tradisional Indonesia pada pulau-pulau di sekitar Kepulauan Ashmore dan Laut Timor yang menjadi wilayah Australia (Hurst 1987, 349). Tetapi hari berikutnya, Indonesia menolak visa masuk bagi turis-turis Australia. Akibatnya, 180 orang turis asal Australia tertahan di Bandara Ngurah Rai Bali dan bahkan sebagian ada yang terpaksa berangkat ke tempat tujuan lain atau kembali ke Australia. Di Bandara Polonia, Medan, empat turis Australia dipaksa kembali ke Kuala Lumpur dan seorang pilot Australia yang menerbangkan pesawat Australia dari Colombo, Sri Lanka, dan melakukan transit di Medan menghadapi interogasi ketat sebelum diijinkan menginap semalam (Tempo 1986).

Menghadapi pencabutan visa masuk ini, Australia melakukan protes diplomatik keras melalui Dubes Australia di Jakarta. Di Canberra, Menlu Australia memanggil Dubes Indonesia untuk menjelaskan kasus ini (Nagy 1986). Karena protes ini, Indonesia melunakkan sikap, menarik kembali tindakan pencabutan visa bagi turis Australia (Byrnes 1986c, 1-4). Meski demikian, sejumlah pejabat Indonesia tetap mengecam sikap media Australia. Dengan sangat emosional, Menteri Penerangan, Harmoko, mendeskripsikan tulisan Jenkins sebagai model jurnalisme alkohol yang jauh dari kebenaran (Merdeka, 24 April 1986). Panglima ABRI, Jenderal Beni Moerdani, mengatakan tulisan Jenkins merupakan kampanye yang mencoreng dan menghina Kepala Negara, suatu bukti usaha campur tangan masalah dalam negeri. Moerdani sampai mengatakan, Indonesia tidak menganggap penting bantuan militer Australia kepada Indonesia (Kassim 1986, 1).

Kasus ini, dikenal luas sebagai Jenkins Affair, telah mengakibatkan hubungan bilateral Indonesia-Australia memasuki tahapan yang paling dingin. Implikasinya mempengaruhi berbagai aspek hubungan. Namun demikian, pemerintah kedua Negara menyadari betul bahwa meskipun banyak perbedaan antara Indonesia dan Australia, Jenskins Affair sebaiknya segera berakhir. 
Dalam perdebatan di Parlemen Australia, 29 April 1986, PM Bob Hawke mengatakan, pemerintahnya tetap serius membangun hubungan yang konstruktif dengan Indonesia. Walaupun demikian, Hawke berargumen, Indonesia harus menerima kenyataan Australia sebagai negara dengan sistem pers bebas dan pemerintah tidak mempunyai kontrol absolut seperti halnya di Indonesia. Untuk itu, kedua pemerintah harus meninggalkan semua perbedaan dan mencari formula terbaik untuk memperbaiki hubungan bilateral (Commonwealth Parliamentary Debates, House of Rep., 1986, 2627-8).

Tidak lama kemudian, pernyataan ini diikuti oleh beberapa tindakan nyata. Tanggal 17 Mei 1986, Menteri Imigrasi Australia, Chris Hurford, diutus mengunjungi Jakarta, mengawali upaya diplomatik memperbaiki hubungan. Meski tidak dinyatakan secara terbuka, hasil kunjungan ini nampaknya positif. Hurford mendapat undangan untuk mengunjungi langsung Timor Timur (Byrnes 1986d, 12). Momentum positif ini berlanjut ketika Menlu Australia, Bill Hayden, mengadakan pertemuan penting dengan Menlu Indonesia, Mochtar Kusumaatmadja, di Manila 28 Juni 1986. Di akhir pertemuan itu Menlu Australia mengeluarkan pernyataan bahwa di samping terjadinya krisis akibat pemuatan artikel Jenkins, hubungan kedua negara berjalan seperti biasa. Meski demikian, krikil-krikil yang mengganjal hubungan belum berhasil seluruhnya disingkirkan. Upaya Canberra mempengaruhi Indonesia mencabut larangan masuk bagi jurnalis Australia belum berhasil. Jurnalis terakhir asal Australia yang bekerja untuk Australian Financial Review tetap harus meninggalkan Jakarta pada akhir 1986 setelah visa kerjanya tidak diperpanjang.

Untuk mengatasi ini, Menlu Hayden melakukan upaya diplomatik lain. Pada bulan Mei 1987, Hayden melakukan persinggahan di Jakarta dalam lawatannya ke Eropa. Ia mengadakan diskusi penting dengan para pejabat Indonesia, termasuk dengan Presiden Soeharto, mengenai larangan masuk bagi jurnalis Australia. Hayden nampaknya sadar bahwa semakin lama masalah ini tidak teratasi, semakin banyak pula potensi kesulitan yang akan timbul (Byrnes 1987, 2). Meski belum mendapat hasil maksimal, Hayden mendapat indikasi bahwa kemungkinan larangan masuk bagi jurnalis Australia ke Indonesia segera berakhir (Peake 1987).

Hingga akhir 1987, hubungan Indonesia-Australia secara berangsur membaik. Perundingan mengenai landas kontinen Celah Timor dibuka kembali. Awal 1988, mulai beredar khabar bahwa larangan masuk terhadap jurnalis Australia segera dicabut. Hal ini terbukti benar, ketika Februari 1988 Indonesia mengijinkan Asosiasi Pers Australia (Australian Associated Press/AAP) mendirikan bironya di Jakarta. Ini dilanjutkan dengan kunjungan Menteri Pos-Telekomunikasi dan 
Pariwisata, Soesilo Soedarman, bulan Agustus ke Australia. Inilah kunjungan resmi pejabat pemerintah Indonesia semenjak Jenkins Affair, yang sekaligus mengindikasikan kesediaan Indonesia untuk memperbaiki hubungan dengan Australia (Hidayat 1988; Ecclesston 1988).

Di dalam semua upaya memperbaiki hubungan ini, peran yang dimainkan Menlu kedua negara, Bill Hayden dan Mochtar Kusumaatmadja, sangat substansial. Keduanya tidak saja berhasil menginisiatifi usaha-usaha diplomatik perbaikan hubungan, tetapi juga mampu meletakkan dasar yang cukup kokoh demi perbaikan hubungan bilateral lebih lanjut antara Indonesia dan Australia. Pada akhir tahun 1988 kedua Menlu ini digantikan oleh Gareth Evans di Australia dan Ali Alatas di Indonesia.

Meskipun kedua Menlu baru diwarisi situasi hubungan yang positif, keduanya mengakui bahwa tugas-tugas yang dihadapinya tidak mudah. Dalam sebuah wawancara pada tahun 1995, Alatas mengatakan bahwa salah satu tugas yang dianggapnya urjen ketika pertamakali ditunjuk menjadi Menlu adalah mengatasi hubungan bilateral IndonesiaAustralia yang tidak stabil (Kompas, 28 Mei 1995, 2). Sementara itu, semenjak awal Evans memperlihatkan keinginan kuat untuk memperluas bidang-bidang kerjasama antar kedua negara termasuk pada level multilateral. Ia berargumen bahwa jika pemerintah kedua negara dapat menemukan kepentingan-kepentingan yang identik tidak saja pada level bilateral tetapi juga pada level multilateral, kedua negara mampu menciptakan hubungan bilateral yang lebih kuat (Ecclesston 1988b, 13). Dengan demikian, semenjak awal kedua Menlu mempunyai persepsi yang sama tentang pentingnya hubungan Indonesia-Australia dan keduanya pun berkeinginan untuk membangun dan mengarahkan hubungan tersebut ke dalam situasi yang masuk akal (sensible) dan produktif.

Hanya beberapa minggu setelah diangkat, Menlu Evans mengunjungi Jakarta tanggal 22 hingga 25 Oktober 1988. Walau ini adalah kunjungan resmi pertamanya sebagai Menlu ke Jakarta, Evans mendapat kesempatan untuk mendiskusikan banyak masalah dengan para pejabat Indonesia. Evans sendiri menilai kunjungannya ini bernilai positif karena dia mampu melakukan konsolidasi personal yang dianggapnya merupakan basis yang menguntungkan bagi pengembangan hubungan bilateral Indonesia-Australia selanjutnya (Scott 1988, 11). Di Australia, banyak kalangan yang menilai kunjungan ini berhasil (Dallmeyer 1988, $3)$.

Bulan Maret 1989, Menlu Alatas melakukan kunjungan balasan ke Australia, suatu kunjungan yang oleh sebagian media Australia dianggap 
menunjukkan wajah persahabatan Indonesia (Williams 1989, 3). Di samping itu, dapat dipastikan bahwa kunjungan ini menunjukkan dengan jelas respons positif Indonesia terhadap pikiran-pikiran yang sebelumnya telah dikaji selama kunjungan Evans ke Jakarta. Ini tergambar dari apa yang dinyatakan Alatas bahwa dia sependapat dengan rekannya Evans yang menilai pentingnya hubungan bilateral kedua negara (Alatas 1989, 88).

Setelah terlibat dalam diskusi tiga hari yang intens, kedua Menlu secara resmi bersepakat bahwa disamping berbagai perbedaan yang ada, Indonesia dan Australia mempunyai banyak kepentingan yang setara dalam berbagai bidang dan hal ini diakui merupakan titik tolak untuk membangun hubungan yang stabil. Secara resmi hasil pembicaraan kedua Menlu disebut Kerangka Kerjasama Baru Hubungan IndonesiaAustralia (A New Framework for the Australia-Indonesia Relationship) yang diringkas sebagai berikut.

Pertama, kedua Menlu “... affirmed the common desire of their two Governments for good-neigbourly, mutually beneficial relations, and agreed to a new framework for the future conduct of the relationship". Kedua, sepakat menyelenggarakan diskusi level meneteri secara regular yang dilakukan sebagai "... forum for frequent consultation and cooperation in the management of relations between the two nations, and annual official talks will be reinstitued". Ketiga, bahwa "The Australia Indonesia Ministerial Meeting (AIMM), to be constituted by the Foreign Ministers of the two countries (and other Ministers as and when appropriate), will be convened at least every 18 months, or more frequently if circumstances so require", yang tujuannya adalah "to review development in Australia-Indonesia relations with the objective of cooperative management of the relationship between the two countries" dan "to consult on regional and global political and economic issues of concern to Australia and Indonesia" (Backgrounder 1989). Di samping itu, kedua Menlu juga sepakat untuk mengadakan pembicaraan reguler pada tingkat pejabat senior yang kemudian dikenal dengan Pertemuan Pejabat Senior Australia Indonesia (Australia Indonesia Senior Officials Meeting/ AISOM). Pertemuan AISOM direncanakan setahun sekali atau sesuai kebutuhan (Backgrounder 1989).

Selain kesepakatan di atas, kedua pihak juga setuju terhadap dua hal lain. Pertama, pembentukan Institut Australia Indonesia yang tugas utamanya adalah membantu pemerintah kedua pihak untuk mengidentifikasi bidang-bidang praktis di mana pengertian yang lebih baik bisa diperluas. Kedua, Evans dan Alatas juga sepakat membina hubungan personal yang lebih baik dan berniat untuk lebih sering menggunakan hubungan telepon langsung (hotline channels) yang 
dianggap penting untuk mendukung hubungan diplomatik AustraliaIndonesia selanjutnya (Bruer 1989, 3).

Kerangka kerjasama baru di atas jelas merupakan kesepakatan resmi baru yang dibangun untuk memperbaiki dan sekaligus meningkatkan mutu hubungan bilateral Indonesia-Australia. Untuk itu, beberapa hal perlu diberi catatan khusus. Kerangka kerjasama ini mengakui kendalakendala masa lalu yang dihadapi dalam rangka memperbaiki hubungan bilateral, dan sekaligus mengakui dibutuhkannya langkah lebih lanjut untuk membangun manajemen hubungan baru. Penekanan pada keuntungan-keuntungan bilateral, menunjukkan bahwa kedua pihak bermaksud mewujudkan hubungan melalui kerjasama-kerjasama yang bersifat konkrit dan pragmatis, yang dianggap potensial mencegah terjadinya krisis.

Muatan kerangka kerjasama baru itu juga memperlihatkan adanya keyakinan keduabelah pihak, bahwa selain jaringan hubungan yang dibangun pada dan melalui tingkat diplomatik resmi, hubunganhubungan yang sifatnya personal antar para pejabat yang duduk dalam institusi-institusi resmi juga perlu dibangun. Ini dianggap mempunyai kontribusi penting terhadap upaya-upaya penyelesaian konflik, sekaligus menjadi salah satu langkah untuk menjembatani perbedaanperbedaan persepsi dan pandangan politik yang muncul akibat perbedaan budaya. Langkah ini diawali dengan kesepakatan kedua Menlu untuk sesering mungkin menggunakan jaringan komunikasi langsung (hotline chanels). Inilah titik yang menandai lahirnya Diplomasi Pertemanan (Mateship Diplomacy) dalam hubunga Indonesia-Australia.

Selanjutnya, melalui kerangka kerjasama baru ini, kedua pihak membangun diskursus baru dalam mengelola hubungan bilateral. Kerangka kerjasama ini mengandung argumen-argumen dan kesepakatan-kesepakatan baru tentang bagaimana hubungan bilateral kedua negara seharusnya dikelola agar efektif dan produktif, termasuk mengkonsentrasikan kerjasama pada bidang-bidang di mana kedua negara mempunyai kesetaraan kepentingan (common interest). Hal ini diyakini mampu menjadi faktor yang memberi motivasi (motivating factor) terhadap stabilitas hubungan di masa depan. Kerangka kerjasama ini secara tidak langsung 'meminggirkan' (sideline) argumen lama mengenai perbedaan kultur sebagai sumber sekaligus kendala terhadap sulitnya menciptakan hubungan bilateral yang stabil. Perbedaan kultur adalah fakta yang memang sulit diubah. Tetapi dengan memberi dasar argumen baru - penekanan pada soal keuntungan timbal balik yang seimbang dari setiap kerjasama yang dibangun kedua negara - perbedaan kultur tidak lagi dipandang sebagai kendala utama, 
justru sebaliknya dilihat sebagai potensi di mana kedua negara dapat membangun kerjasama yang seimbang.

Muatan kerangka kerjasama baru secara implisit juga mengesampingkan pandangan lama bahwa pihak Australia-lah yang paling berkepentingan terhadap terciptanya hubungan baik antara Indonesia dan Australia. Kesepakatan untuk bekerjasama dalam banyak bidang mengindikasikan bahwa pihak pemerintah Indonesia dan Australia mempunyai tanggungjawab bersama (twin responsibility) di dalam menjaga stabilitas hubungan. Keinginan kedua pihak untuk juga menjalin kerjasama pada isu-isu berskala regional dan global, menunjukkan kehendak kuat mengarahkan substansi hubungan bilateral dari yang tadinya hanya terfokus pada isu-isu politik-keamanan berskala sempit, ke suatu format yang lebih luas, mencakup lebih banyak persamaan-persamaan kepentingan.

\section{Momentum Keating}

Ketika Paul Keating terpilih menjadi Perdana Menteri Australia pada bulan Desember 1991, Diplomasi Pertemanan mendapat momentum baru. PM Keating memutuskan melakukan kunjungan resmi luar negeri pertamanya ke Indonesia, suatu keputusan yang jelas menunjukkan bahwa ia berkeinginan untuk semakin memperkuat hubungan bilateral Indonesia-Australia. Keating-lah PM Australia yang pernah menyatakan bahwa tidak ada negara yang lebih penting bagi Australia selain Indonesia. Bahkan dia juga pernah mengakui bahwa salah satu prioritas terpenting yang dipikirkannya sesaat setelah terpilih menjadi PM adalah menjamin berlangsungnya hubungan bilateral Indonesia-Australia yang stabil. Inilah alasan utama mengapa dia memutuskan untuk melakukan kunjungan pertama ke Indonesia (Keating 1995, 201-6).

Keating berargumen, sudah terlalu lama kedua negara hanya memfokuskan hubungannya pada isu-isu politik yang eksklusif. Akibatnya, tidak banyak orang Australia mengerti pentingnya Indonesia, termasuk kemajuan ekonomi yang telah dicapainya serta peluangpeluang yang dapat dimanfaatkan Australia (Keating 1995, 201-6). Pandangan demikian nampaknya disetujui oleh Presiden Soeharto. Karena itu, dalam kunjungan pertama Keating ke Jakarta kedua pemimpin sepakat bahwa segera perlu dibentuk suatu mekanisme resmi untuk menjembatani hubungan kedua negara. Realisasinya, kedua pemimpin sepakat membentuk Forum Kementerian Indonesia-Australia (Australia-Indonesia Ministerial Forum/AIMF) yang beranggotakan terutama Menteri-Menteri dengan portofolio ekonomi (Keating 1995, 201-6). 
Struktur AIMF terdiri dari dua kelompok kerja utama, kerjasama di bidang pertanian dan makanan serta kerjasama di bidang perdagangan, industri dan investasi. Kelompok kerja pertama terdiri dari enam gugus kerja (taskforce); daging dan peternakan, susu, manajemen pertanahan dan air, pengembangan dan penelitian pertanian, pemrosesan makanan, dan pemrosesan makanan termasuk sistem penyimpanan, transportasi dan distribusinya. Kelompok kerja kedua terdiri atas tiga sub-kelompok utama; perdagangan dan investasi termasuk jasa, hak milik intelektual, dan kerjasama di bidang industri yang secara khusus meliputi pembuatan kapal, standard industri, komponen otomatik, konstruksi dan konsultasi teknik, tekstil, pakaian dan alas kakai (footwear), manajemen lingkungan, aerospace, telekomunikasi, tenaga listrik, serta perlengkapan medis dan ilmu pengetahuan (East Asia Analytical Unit 1994, 337).

Struktur AIMF di atas dengan jelas menunjukkan betapa luasnya bidang-bidang potensial yang dapat dikelola bersama Indonesia dan Australia. Di samping itu, struktur ini memungkinkan kedua pemerintah untuk meningkatkan substansi diskursus baru hubungan bilateral kedua negara ke suatu tingkat yang lebih konkrit. Dengan kata lain, pemerintah Indonesia dan Australia berhasil menterjemahkan ide-ide yang termuat dalam kerangka kerjasama 1989, ke dalam kebijakankebijakan yang lebih konkrit dan jelas (visible).

Aspek penting lain yang terlihat dari kunjungan pertama Keating ke Jakarta adalah langkahnya meneruskan gaya Diplomasi Pertemanan yang telah dirintis Menlu Gareth Evans dan Ali Alatas. Keating memulai suatu bentuk hubungan personal yang dekat dengan Soeharto. Sudah umum diketahui bahwa semenjak itu PM Keating cukup sering mengadakan hubungan telepon langsung dengan Presiden Soeharto dan mengadakan konsultasi langsung terhadap berbagai hal. Selama empat tahun menjadi PM, Keating melakukan kunjungan resmi sebanyak enam kali. Jika dibandingkan dengan PM sebelumnya, Bob Hawke, dalam sembilan tahun sebagai PM dia hanya sekali mengunjungi Indonesia. Dengan demikian, Keating mempunyai rekor tersendiri.

Studi lain juga menunjukkan bahwa faktor Keating ini jugalah yang berpengaruh terhadap perubahan sikap Indonesia terhadap Kerjasama Ekonomi Asia Pasifik (Asia Pacific Economic Cooperation/APEC). Pengaruh diplomasi Keating dan hubungannya yang dekat dengan Soeharto, membantu mendorong Indonesia yang tadinya agak ragu-ragu dengan ide perdagangan bebas APEC, menjadi salah satu negara yang sangat mendukung (Rezasyah 1994, 320-32). Diplomasi Pertemanan Keating-lah yang cukup instrumental terhadap tercapainya Deklarasi Bogor, melalui mana anggota APEC sepakat membuka kawasan perdagangan bebas antar anggota yang dimulai tahun 2020. Adalah 
model diplomasi yang sama ini juga yang membantu Indonesia dan Australia mencapai kesepakatan bersejarah, penandatanganan perjanjian keamanan pada bulan Desember 1995 (Lowry 1996).

Secara garis besar, apa yang disepakati melalui Kerangka Kerjasama Baru 1988 segera diwujudkan oleh pemerintah kedua negara. Seperti telah disepakati, Konsultasi Tingkat Menteri yang terjadwal delapanbelas bulan sekali, segera dimulai. Pertemuan pertama diadakan di Bali pada 1990 dan kedua di Canberra tahun berikutnya. Kunjungan setingkat menteri, termasuk kunjungan pimpinan militer, meningkat drastis. Antara 1989-1991 saja misalnya, empatbelas menteri Indonesia mengunjungi Australia (Effendi 1991, 6-7). Kunjungan-kunjungan serupa dari pihak Australia juga meningkat drastis. Dalam kapasitasnya sebagai Menteri Luar Negeri dan Perdagangan, Senator Gareth Evans misalnya, telah melakukan lawatan resmi sebanyak empatbelas kali antara 1988-1995 (Evans 1996, 13). Jumlah ini melebihi duapuluh kali jika kunjungan resmi Evans antara 1994-1996 juga ikut dihitung. Secara umum, antara Agustus 1988-Juni 1994 berlangsung 87 kali kunjungan bilateral setingkat menteri, 35 dari Indonesia dan 52 dari pihak Australia Evans and Grant 1995, 201-2). Dari jumlah kunjungan timbal balik yang meningkat ini, tentu saja cakupan isu dan kepentingan yang dibicarakan meliputi banyak hal.

Bersamaan dengan meningkatnya lalulintas kunjungan pejabat pemerintah antar kedua negara, upaya-upaya kerjasama pada tingkat multilateral antara Indonesia dan Australia juga mulai digalakkan secara aktif. Bidang yang paling menonjol adalah kerjasama kedua negara dalam rangka mencari solusi penyelesaian konflik Kamboja. Tidak dapat dipungkiri bahwa kerjasama pemerintah kedua negara mempunyai kontribusi besar terhadap penyelesaian komprehensif masalah Kamboja pada tahun 1993. Dalam rangka ini, Menlu kedua negara, Gareth Evans dan Ali Alatas, kembali memperlihatkan kerjasama yang saling mendukung, dan kedekatan hubungan kedua Menlu banyak membantu diplomasi kedua negara dalam penyelesaian masalah Kamboja (Evans 1994, 1-14).

Kecenderungan membaik dan meningkatnya saling pengertian antar kedua negara semakin terlihat ketika pada bulan Juli 1991, Indonesia mengangkat Sabam Siagian, jurnalis senior, menjadi Duta Besar Indonesia untuk Australia. Inilah kali pertama dalam sejarah Pemerintahan Orde Baru, seorang jurnalis diangkat menjadi Duta Besar, meskipun praktek demikian sudah cukup sering di tahun 1950-an.

Mengingat bahwa Sabam adalah seorang jurnalis senior yang syarat pengalaman, pengangkatannya tentu saja signifikan dalam konteks hubungan Indonesia-Australia. Keputusan pemerintah Indonesia 
menunjuk dan mengangkat Sabam Siagian jelas mengindikasikan bahwa Indonesia memberi perhatian serius terhadap hubungan baiknya dengan Australia. Sebagai seorang jurnalis senior berpengalaman, Sabam diperkirakan figur pilihan tepat untuk pos Duta Besar Indonesia di Canberra. Pengalamannya diharapkan mampu menanggulangi potensi terganggunya hubungan kedua negara akibat cara-cara pemberitaan pers Australia. Keputusan ini tentu saja dilandasi dengan tujuan yang baik, yaitu mempertahankan stabilitas dalam rangka meningkatkan kualitas hubungan bilateral Indonesia-Australia. Alasan ini diakui oleh Menlu Alatas sebagaimana yang dikatakannya setelah pengambilan sumpah Duta Besar Sabam Siagian. Menlu Ali Alatas mengatakan bahwasanya pengangkatan sebagai Duta Besar Baru Indonesia di Australia, secara khusus bertujuan untuk memperkuat interaksi dan dialog yang lebih baik dengan masyarakat Australia, terutama dengan masyarakat pers dan organisasi-organisasi nonpemerintah (Hill 1991, 7).

\section{Simpulan: Menatap ke Depan}

Diplomasi Pertemanan (Mateship Diplomacy) adalah bentuk hubungan diplomasi yang dikembangkan sebagai mekanisme pendukung hubungan diplomasi resmi. Diplomasi ini menekankan pentingnya hubungan personal antar pejabat yang sifatnya tidak resmi, suplemen terhadap mekanisme diplomatik resmi, dan bisa berwujud berbagai aktivitas. Wujud yang paling penting adalah penggunaan saluran komunikasi langsung (hotline chanels) antar top elit, seperti misalnya antara Menteri Luar Negeri atau antara Presiden dan Perdana Menteri.

Sosok low-profile Presiden Jokowi nampaknya sangat cocok untuk kembali membuka model diplomasi serupa. Metode "blusukan" yang kerap dipakai sebagai cara mendekatkan diri langsung dengan masyarakat, tentu menjadi modal yang kuat untuk membangun "Diplomasi Blusukan" (Blusukan Diplomacy) di dalam menata hubungan Jakarta-Canberra. Gaya Presiden Jokowi tentu sangat potensial memberi ruang terhadap meningkat dan meluasnya hubungan personal (people-to-people relations) antara Indonesia dan Australia. Presiden Jokowi boleh saja minim latarbelakang urusan politik luar negeri, tetapi sebagaimana pernah dinyatakannya secara terbuka bahwasanya boleh saja dia mempunyai wajah seorang yang berasal dari kampung, tetapi dia mengakui mempunyai otak internasional; "I may have the face of someone who comes from village, but I have an international brain (Bland 2014).

Karir bisnis Jokowi sebelum terjun ke politik telah mengantarnya untuk berhubungan bisnis di berbagai belahan dunia. Visi politik luar 
negerinya yang menekankan asas fungsional dari pertemanan yang dibangun tentu juga potensial mengoptimalkan sinergi kepentingan di berbagai bidang antara Indonesia dan Australia. Hal ini penting karena melihat Diplomasi Pertemanan antara Australia dan Indonesia sejak tahun 1988 yang tumbuh dari kesadaran bersama atas realitas hubungan bilateral yang rentan terhadap isu-isu politik sempit; hak asasi manusia, persepsi Australia tentang ancaman dari Utara, dan gaya pers Australia dalam memberitakan tentang Indonesia. Dalam prosesnya, kesadaran bersama ini perlu direalisasikan oleh Menteri Luar Negeri kedua Negara saat ini, sebagaimana Ali Alatas dan Gareth Evans, menyepakati Kerangka Kerjasama Baru 1989. Kedua pihak merasa perlu bidang-bidang kerjasama diperluas tidak saja pada tingkat bilateral tetapi juga pada tingkat multilateral.

Fakta telah membuktikan bahwa pola diplomasi serupa dipomasi pertemanan -apakah nantinya Blusukan Diplomacy- mempunyai peranan potensial yang dapat disumbangkan terhadap stabilitas hubungan Indonesia-Australia. Di samping terciptanya mekanisme resmi yang berfungsi meningkatkan bidang-bidang kerjasama yang semakin luas, hubungan baik yang dikembangkan antar elit kedua negara, ternyata menciptakan suasana yang konstruktif ketika kedua pihak menghadapi konflik yang potensial mengganggu stabilitas hubungan.

Terdapat momentum baru yang juga potensial menjadi modal memperkokoh hubungan Indonesia-Australia ke depan, yaitu naiknya Malcolm Turnbull menggantikan Tony Abbott. Gaya foto selfi yang dilakukan Malcolm Turnbull ketika diajak blusukan Presiden Jokowi ke Pasar Tanah Abang dalam kunjungannya ke Jakarta baru-baru ini, boleh jadi indikasi kuat bahwa kedua pemimpin ini siap memperkokoh kembali hubungan Indonesia-Australia dengan mengkombinasikan Blusukan Diplomacy ala Jokowi dengan Selfie Diplomacy ala Perdana Menteri Turnbull. Jika prinsip-prinsip dasar sebagaimana diuraikan di atas diletakkan kembali dengan gaya kepemimpinan kedua pemimpin baru ini, maka niscaya hubungan Garuda dan Kanguru akan secepatnya kembali stabil seperti sediakala.

\section{Daftar Pustaka}

\section{Buku}

Catley, Bob \& Dugis, Vinensio, 1998. Australian Indonesian Relations Since 1945, The Garuda and The Kangaroo. Aldershot: Ashgate. 
Effendi, Buchari, 1991. "Indonesia-Australia Economic Relations," dalam H. da Costa. Australian Aid to Indonesia, editor. Melbourne, Centre of Southeast Asian Studies, Monash University.

Evans, Gareth, 1994. "The Comprehensive Political Settlement to the Cambodian Conflict: An Exercise in Cooperating for Peace," dalam Hugh Smith. International Peace Keeping, Building on the Cambodian Experience, editor. Canberra, Australian Defence Studies Centre.

\& Grant, Bruce, 1995. Australia's Foreign Relations In the Wolrd of the 1990s, 2nd ed. Melbourne: Melbourne University Press.

-------, 1996. "Australia and Indonesia: Neighbours for half a Century," dalam Colin Brown. Indonesia, dealing with a neighbour, editor. St. Leonards, NSW: Allen \& Unwin.

Keating, Paul, 1995. "Australia and Indonesia," dalam Mark Ryan. Advancing Australia, The Speeches of Paul Keating, Prime Minister, editor. Sydney: Big Picture.

\section{Artikel Jurnal}

Alatas, Ali. 1989. "Some Thoughts on Indonesian-Australian Relations," Jurnal Luar Negeri, 12.

Hurst, John. 1987. "A Clash of Culture; Indonesia and the Australian Media," The Australian Quarterly, Spring and Summer.

\section{Tesis}

Dugis, Vinsensio. 1996. "Australian-Indonesia Relations: A Study of Political, Economic and Defence Cooperation", MA Thesis submitted at the Department of Politics, University of Adelaide, Australia.

\section{Artikel Media Cetak \& Online}

Bruer, Mark, 1989. "Evans and Alatas reestablish a close relationship," The Age, 4 March.

Byrnes, Michael, 1986a. "Indonesian Minister cancels trip after newspaper article," Australian Financial Review, 14 April.

-------, 1986b. "Jakarta freezes border talks," Australian Financial Review, 17 April.

--------, Greg Earl, and Tony Grant-Taylor. (1986c). "Indonesia backs down as moderates prevail," Australian Financial Review, 24 April. 
--------, 1986d. "Hurford visit aims to rebuild relations," Australian Financial Review, 19 May.

--------, 1987. "Hayden working to heal rift between Canberra - Jakarta," Australian Financial Review, 5 May.

Dallmeyer, James, 1988. "Indonesian talks 'excellent, constructive,", Canberra Times, 24 October.

Ecclesston, Roy, 1988a. "Neigbours who don't want to know us," The Weekend Australia, 20-21 August.

--------, 1988b. "Evans' twofold strategy," The Australian, 27 October.

Hidayat, Syarif, 1988. "Indonesia Benar-Benar Mau Dekat Dengan Australia," Angkatan Bersenjata, 12 September.

Hill, David, 1991. "Jakarta's new man in Canberra," Inside Indonesia, No. 28.

Jenkins, David, 1986a. "After Marcos now the Soeharto millions," The Sydney Morning Herald, 10 April.

-------, 1986b. "The Quiet, Bald Moneymaker of Jakarta's Elite,” The Sydney Morning Herald, 10 April.

Kassim, Yang Razali, 1986. "Row Over Sydney Morning Herald Articles-Murdani Blasts Aussie paper," The Strait Times, 22 April.

Nagy, Anthony, 1986. "Envoy Puts on Bold Front in Visa Shuffle," The Age, 24 April.

Peake, Ross, 1987. "Indonesia may soon lift ban on journalists," The Australian, 5 May.

Robert, George, 2015. "Bali Nine: Indonesian president defends refusal to grant clemency to Andrew Chan, Myuran Sukumaran and other drug criminals", http://www.australiaplus.com/international/2015-02-12/ [diakses 18 November 2015].

Scott, Jason \& Chatterjee, Neil, 2015. "Indonesia Executions Spur Australia to Recall Ambassador", http://www.bloomberg.com/news/articles/2015-04-28/ [diakses 18 November 2015].

Scott, Keitt, 1988. "Trade with Indonesia outranks human rights," Canberra Times, 29 October.

Walters, Patrick, 1986a. "Article not true, says Indonesia," The Sydney Morning Herald, 14 April.

-------, 1986b. “Journalists face Indonesian ban," The Sydney Morning Herald, 15 April.

Williams, Louise, 1989. "Visit sets scene for Jakarta meetings," The Sydney Morning Herald, 27 February.

Kompas, 28 Mei 1995.

Merdeka, 22 April 1986.

Tempo, 3 Mei 1986. 


\section{Working Paper}

Connelly, Aaron L., 2014. Indonesian foreign policy under President Jokowi, Lowy Institute Analysis Paper.

Lowry, Bob, 1996. Australia-Indonesia Security Cooperation: For Better or Worse? Working paper No. 299, Canberra, Strategic \& Defence Studies Centre of Australian National University.

Robert, Christopher B. \& Habir, Ahmad D., 2014. Australia's relations with Indonesia; Progress despite economic and socio-cultural constraints?, National Security College Issue Brief No. 11.

\section{Dokumen Resmi}

East Asia Analytical Unit, Department of Foreign Affairs and Trade, 1994. Expanding Horizons, Australia and Indonesia into the 21st Century. Canberra, AGPS.

Backgrounder, No. 467, 15 March 1989.

Commonwealth Parliamentary Debates, House of Rep., Vol. 148, 1986. 